\title{
脂肪酸リモデリング，脂肪滴形成と脂肪毒性 Fatty Acid Remodeling, Lipid Droplet Formation and Lipotoxicity
}

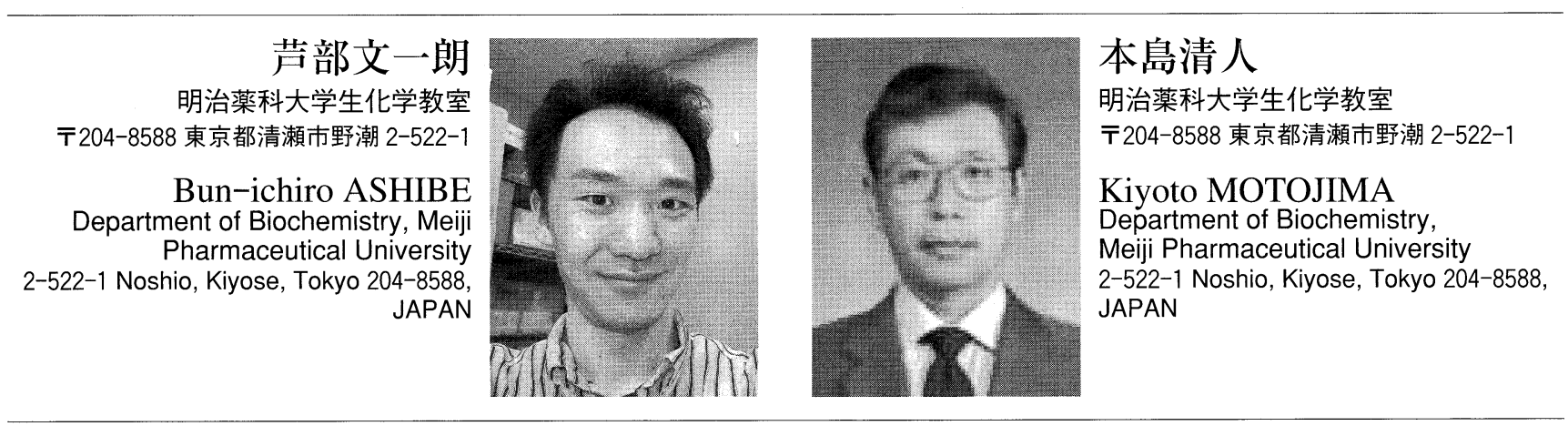

論文要旨 : ゲノム解析が進み, 脂肪酸代謝に関わる䤃素と調節因子の数の多さと, 多様性と多重性が明ら かになった。遺伝子産物である酶素の発現と活性, それらの調節の詳細については今後の研究を待たなけれ ばならないが, 現時点でも食物由来の飽和および不飽和脂肪酸の体内脂質代謝に及ぼす影響を分子レベルで 考察を始めることが可能となった。中でも，過剩な脂質が細胞機能を障害する脂肪毒性は，多くの疾患の原 因と考えられており，その発生機構については多くの研究がなされている。本総説では，まず脂肪酸りモデ リング系について，その食物由来の脂質に対する適応システムとしての重要性と柔軟性を概説する。次いで 脂肪毒性の発生機構として提出されている代表的な仮説の検証を行いながら, 防御機構としての脂肪酸りモ デリング系と脂肪滴形成の組織特異的な意義について述べる。

\begin{abstract}
Genome analysis has made great progress in our understanding of a large number of diverse and overlapping enzymes and regulators involved in fatty acid metabolism. Although investigation on the regulation of expression and activities of these enzymes has to await further progress, it is becoming possible to consider the effect of dietary saturated and unsaturated fatty acids on whole-body lipid metabolism at the molecular level. Based on this progress, several mechanisms have been proposed to explain how an excess fat impair the cellular functions (so-called lipotoxicity). In this review, we will present and discuss the regulation of fatty acid remodeling system and lipid-droplet formation and their tissue-specific roles in fatty acid-induced lipotoxicity.
\end{abstract}

Key words: lipotoxicity, fatty acid remodeling, ER stress, lipid droplet

\section{1 はじめに}

脂肪酸は生体にとって重要なエネルギー源であり, 膜 機能維持のための必須の構成成分であり, シグナル分子 生成の材料であり,ささらはシグナル分子そのものでも ある，という構造的にも機能的にも多面性をもつ。動物 （ヒト）の場合は，この脂肪酸を体内で生合成するとと もに，食物からも脂質の形で大量に取り込む。ヒトが摂 る食物の脂質組成は，ヒトの体内とは異なり，ヒト体内 にはほとんど存在しない脂質成分や高度不飽和脂肪酸が

連絡者: 本島清人

E-mail : motojima@my-pharm.ac.jp
含まれる。これら多様な脂質分子を体内に取り达むヒト は，不要な分子を代謝解毒し，利用可能な分子はその分 子型と量比を整える（リモデリング）必要がある。今ま で総体としてしか捉えられなかった脂肪酸りモデリング が, ゲノム解析の進展にともない, 脂肪酸リモデリング を触媒する酵素アイソファームの存在が明確となったた めに, これら酵素の発現調節や生理的意義を解析し考察 することが可能となった。一方, 細胞内脂肪滴について は，プロテオーム解析技術の発展にともない脂肪滴付着 タンパク質の同定が可能になったのを契機に, 脂肪細胞 以外の脂肪滴の役割に関する研究も進んできた。そこで 本総説では，脂肪毒性を脂肪酸リモデリングと脂肪滴形 
成の観点から考えてみる。

\section{2 脂肪酸と脂肪酸を含む脂質の存在状態}

脂肪酸は細胞内で遊離型ではほとんど存在せず，多く はエステル体として存在する。遊離脂肪酸は脱共役活性 や界面活性化作用の毒性を持ちうるため, 細胞内では速 やかに $\mathrm{CoA}$ 体に変換され，残る遊離脂肪酸も細胞質に もっとも豊富に存在するタンパク質のひとつである脂肪 酸結合タンパク質 (fatty acid binding protein, FABP) にトラップされている。この脂肪酸利用のための初発過 程を触媒する acyl-CoA synthetase は，ヒトゲノム中に 独立した 26 個の遺伝子にコードされており，脂肪酸の 炭素数と不飽和度の違いによる基質選択性はあるもの の, 機能的には多重に overlap していることが知られて いる1)。速やかな脂肪酸の CoA 体への変換が細胞にとっ ていかに重要であるかが推察できる。acyl-CoA からホ スファチジン酸を経て合成される主要な脂質分子型は, 極性をもたないトリアシルグリセロールと，極性をもつ グリセロリン脂質の二つである。さらにコレステロール エステル中では非極性脂質の構成成分として，またス フィンゴリン脂質やスフィンゴ糖脂質中ではエステル体 としてではなくスフィンゴシンとアミド結合し極性脂質 の構成成分として存在する。脂肪酸が極性脂質分子の成 分として存在するか，それとも非極性脂質分子の成分と して存在するかの違いはきわめて重要である。極性をも たない脂質分子は，水環境の中では孤立し，生体膜の成 分ともならないため，いわば生体反応系から隔離された 環境にある。そのためこれらの分子中で存在する脂肪酸 は眝蔵型あるいは不活性型であり，脂肪酸の分子型はリ パーゼによって切り出されるまでは，さほど重要な意味 をもたない。脂肪酸負荷の場合に細胞内で形成される脂 肪滴は，中性脂質をリン脂質が取り囲む形で存在し，大 量の脂肪酸を隔離する役目を果たしている。それに対 し，極性脂質分子はその両親媒性のために，生体膜を構 成し，非極性分子と水の界面にも存在する。したがって その分子型と電荷は，極性脂質と相互作用し生体反応を 触媒するタンパク質の活性に多大な影響を与えうる。

\section{3 膜脂質成分としての飽和脂肪酸と不飽和脂肪酸}

膜の極性脂質の脂肪酸組成変化は，コレステロール含 量とともに膜の流動性を左右し，膜の機能発現に重大な 影響をもつ。一般に脂肪酸の炭素鎖が長くなるほど，不 飽和度が低いほど，膜の流動性は低下する。膜に存在す るタンパク質の機能発現のためには膜の流動性を一定に 維持すること，すなわち膜内コレステロール含量と膜脂 質の脂肪酸組成を，細胞に流入する脂質の質と量のいか
んにかかわらず，一定の範囲内に保つ機構をもつことが 生命維持に必須である。さらに細かく言えば，同一膜内 にあっても，ミクロドメインの脂質組成を維持するとい う精密な調節が重要である。そのため，脂肪酸を含む脂 質を食物から大量に摄取する動物は，外来脂肪酸の鎖長 や不飽和度を，自らに適した脂肪酸組成に変える脂肪酸 リモデリングシステムを進化の過程で発展させる必要が あった。さらに，植物や微生物などのみが生合成し，動 物の体内では合成されることのない鎖長や不飽和の位置 が異なる，あるいは分岐した脂肪酸（異型脂肪酸）への 対応システムも，動物は持つ必要があった。ただ，食物 から入る脂質は一過的であることと，食物により脂肪酸 組成の偏りは著しくても，必ず混合物であることに留意 する必要がある。また，食物から流入する脂質組成を， 直ちにリモデリングしなければならないわけでもない。 上述のように，とりあえず活性をもたない非極性分子に 変換し, 後に述べる脂肪滴として隔離してから徐々に代 謝利用することが可能である。

\section{4 脂助酸リモデリング}

動物の生存のために必須である脂肪酸リモデリングシ ステムは，組織ごとに異なる意味合いをもち，基質特異 性の overlap する多重のシステムが進化の過程で構築さ れてきた。動物体内での脂肪酸生合成は，まず細胞質に おいて脂肪酸合成酵素（fatty acid synthase, FAS）に よって C 16:0 パルミチン酸まで合成される。つづく小胞 体膜上での延長反応も細胞質と同様に acyl-CoA と malonyl-CoAの 4 段階の縮合反応で進むが，FASによる合 成とは異なり acyl carrier タンパク質を必要とせず，CoA 誘導体として鎖長が延長される。すなわち，食事脂肪酸 由来の acyl-CoA はこの系でリモデリングを受ける。こ の律速過程である鎖長延長反応を触媒するのが elongase で elongation of very long chain fatty acid から ELOVL で略記され，ヒトやマウスでは 7 種類が知られる ${ }^{2)}$ 。不 飽和度と鎖長によって各 ELOVL が良い基質とする脂肪 酸が異なることが知られており，飽和あるいは一価不飽 和脂肪酸の鎖長延長反応を触媒する ELOVL $1,3,6$ と， 多価不飽和脂肪酸を鎖長延長する ELOVL 2, 4, 5 の 2 グ ループに大別される。なお，ELOVL 7 については解析 されていない。

一方，ヒトでの脂肪酸の不飽和化は，飽和脂肪酸であ るパルミチン酸あるいはステアリン酸の $\Delta 9$ 位に，最初 のシス型二重結合を導入する stearoyl-CoA desaturase （SCD）と，すでに存在する二重結合とカルボキシ基の 間を不飽和化する fatty acid desaturase（FADS）に大 別される3)。ヒト SCD には 2 種類のアイソフォームが知 
られるが, マウスでは 4 種類報告され, 複雑な遺伝子進 化が示唆されている。またヒトFADSとしてFADS 1 から FADS 6 まで報告されているが，これ以外に他生物 遺伝子との相同性から不飽和化活性が推定されるものも あり，活性との対応を含め，命名も今までのところ十分 には整理されていない。いずれにしても多数の脂肪酸り モデリング酵素が存在し, 内因性と食物由来の脂肪酸の 延長反応と不飽和化が脂肪酸利用系とのバランスの中で 進められる。

\section{5 脂肪酸リモデリングシステムの多様性と多重性}

脂肪酸リモデリング酵素にみられる多様性とは, 個々 の酵素が高い基質特異性をもち固有の反応にかかわる厳 密なリモデリング経路が複数存在する，という意味では ない。ELOVL 4 の欠損がある種の黄斑変性症の原因で あることが明らかにされ4)，この酵素が網膜に多く発現 していることと対応するが，他組織でも発現している。 脳のミエリンのスフィンゴ脂質に重要な極長鎖脂肪酸合 成に関わるとされる ELOVL 1 も，脳以外での組織での 発現レベルは高く，同じ ELOVL が発現している組織に よって異なる役割を演じていると考えられる。また，最 近の Scd $1^{5)}$ や Elovl $6^{6)}$ 遺伝子ノックアウトマウスの解 析でも，これら酵素の特異的な働きが判明したというよ りは，遺伝子完全欠損のわりには通常食飼育下での脂肪 酸組成への影響が小さい。無脂肪食や高脂肪食, 肥満マ ウスとのかけ合わせ等，過大なストレスを与えた時に野 生型との差がみられている。これらの結果は，脂肪酸り モデリングシステムが，1 過程が 1 酵素によって担われ る独立した経路の集まりから成り立っているのではな く, 最終的なバランスを保つように補完しあう多重なシ ステムによっていることを示している。

\section{6 脂肪酸リモデリング酵素群の組織での発現パターン}

代表的な脂肪酸リモデリング酵素のヒト組織での分布 の概略を Table 1 に示す ${ }^{3)}$ 。各リモデリング酵素が重複
する組織特異性をもって発現し, 組織ごとに固有の組み 合わせを持っていることがわかる。これは，各組織に流 入しうる脂肪酸の種類と量, そこで必要とする脂肪酸に 違いがあることを反映している。ただし, Table 1 に示 すのは, mRNAの発現量であり, 各酵素のタンパク質 量さらには酵素活性量については解析が進んでいない。

\section{7 脂肪酸リモデリング系の調節}

脂肪酸合成系とリモデリング系の調節の研究は, 従来 はフィードバックを中心とする翻訳後の酵素活性調節が 主体であった。決してこの段階の調節が重要でなくなっ たわけではないが，昨今の遺伝子発現解析技術の進歩に よって, 生化学的な速度論的解析よりも遺伝子転写調節 レベルの研究が飛躍的に容易になった。その結果, さま ざまな実験系を用いて, 脂肪酸代謝系酵素遺伝子の発現 調節の報告がなされ, 今後もこうした状態が続くものと 予想される。報告される実験結果は, 生物種, 組織, 細 胞株などがさまざまで, 各々の系での脂肪酸リモデリン グは異なる生理的意味をもつため, 統一的な調節の仕組 みは考えにくい。Fig. 1 には, 肝蔵を中心とした脂肪酸 リモデリング系酵素の発現調節を示した。この機構が, 他の組織細胞にもそのまま当てはまるわけではないこと に留意する必要がある。

主要な転写因子は, SREBP とPPAR $\alpha$ である。はじ めはコレステロール代謝調節の主要な転写因子として同 定された SREBP は，そのサブタイプ SREBP 2 がコレス テロール代謝を，SREBP $1 \mathrm{c}$ が脂肪酸代謝を調節する。 通常は前駆体の形で小胞体膜夕ンパク質として存在する SREBP は，膜脂質の変化を感知してゴルジ装置へ移動 し，そこに局在するプロテアーゼによる切断を受け，リ ガンド結合に依存しない形で活性化され, 核内に移行し 転写因子として働く。脂肪酸リモデリングシステムの SCD 1, ELOVL 6, FADS は SREBP 群のターゲット遺 伝子である ${ }^{6)}$ 。後に述べる小胞体ストレスが SREBPを 活性化するという報告が複数ある ${ }^{7)}$ 。脂肪酸の $\beta$ 酸化系

Table 1 代表的な脂肪酸モデリング酵素の各組織における発現 ${ }^{3}$

\begin{tabular}{|c|c|c|c|c|c|c|c|}
\hline & \multicolumn{7}{|c|}{ 脂肪酸リモデリング酵素 } \\
\hline & SCD1 & SCD2 & FADS5 & FADS6 & ELOVL2 & ELOVL4 & ELOVL5 \\
\hline 肝蔵 & 0 & & O & $\bigcirc$ & & & \\
\hline 胎児肝臓 & 0 & & $\bigcirc$ & $\bigcirc$ & $\bigcirc$ & & $\bigcirc$ \\
\hline 精巣 & 0 & & O & $\bigcirc$ & & & $\bigcirc$ \\
\hline 全脳 & O & & 0 & $\bigcirc$ & & 0 & $\bigcirc$ \\
\hline 神経 & & & & & & & \\
\hline 肺 & $\bigcirc$ & & & $\bigcirc$ & & & $\bigcirc$ \\
\hline 腎臓 & & O & $\bigcirc$ & $\bigcirc$ & & & \\
\hline 膵臓 & & O & & & & & \\
\hline 胸腺 & 0 & & 0 & 0 & & O & $\bigcirc$ \\
\hline
\end{tabular}




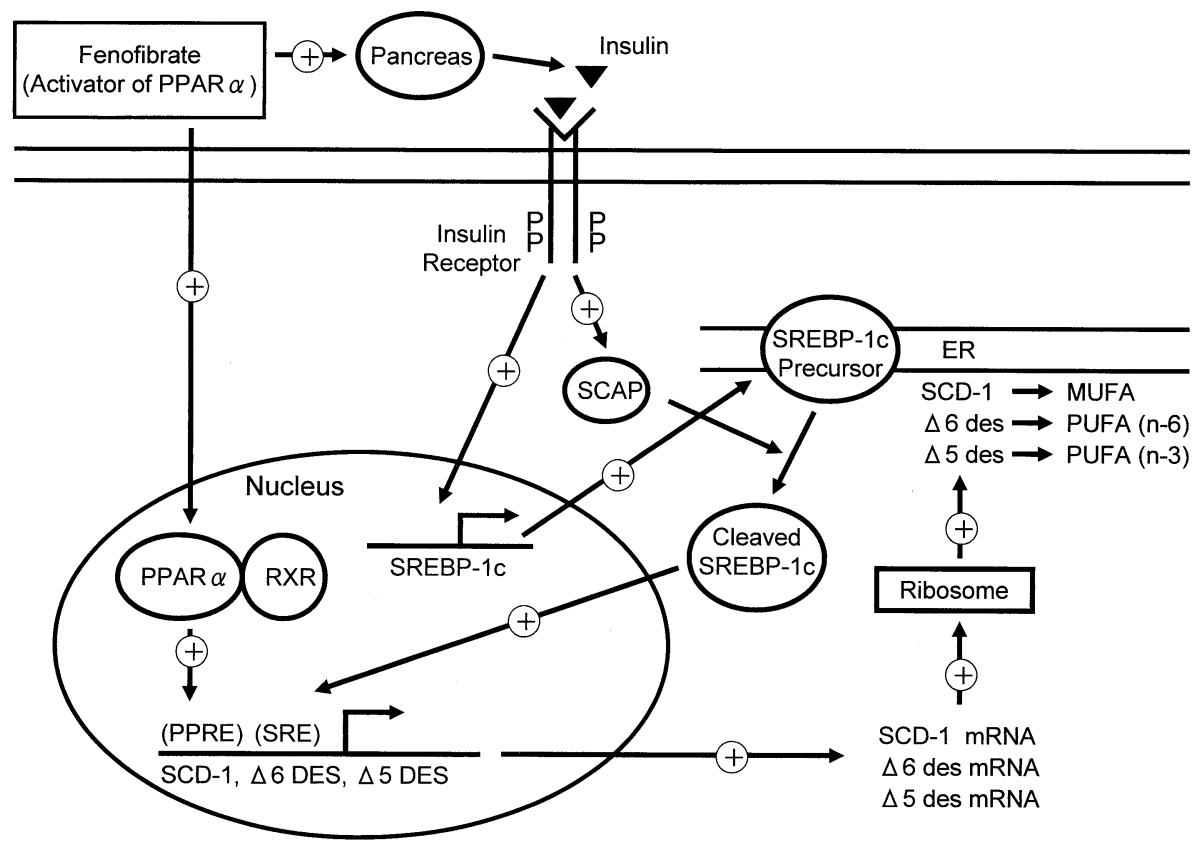

Fig. 1 肝臓における主要な脂肪酸リモデリング系とその転写調節

酵素遺伝子の転写を活性化することが知られるPPAR $\alpha$ は, 脂肪酸リモデリング系酵素遺伝子の転写も活性化す る。PPAR $\alpha$ の活性化は長鎖不飽和脂肪酸あるいはその 代謝物が良いリガンドとなって結合することによるとさ れている。脂肪酸の種類によってアゴニスト活性, 場合 によってはアンタゴニスト活性が異なり，それがリモデ リング系の自己調節機構となっている可能性はある。ま た, PPAR $\alpha$ は小胞体膜の恒常性維持に重大な艿威とな り得る植物由来脂質や生体外異物などの異型脂質分子の 解毒代謝に関わる, P 450 群や $\omega$ 酸化経路の酵素遺伝子 群の転写調節も行っている。

\section{8 脂肪毒性と小胞体ストレス応答}

脂肪細胞以外の細胞は, 対処しきれない脂肪酸流入に よって機能不全に陥るが，この過剩な脂肪酸が起こす悪 影響を脂肪毒性（Lipotoxicity）と呼ぶ。高濃度の脂肪 酸にさらされ続けると, 骨格筋ではインスリン抵抗性, 心筋では収縮不全, 膵 $\beta$ 細胞においてはインスリン分泌 能の低下などが起こることが知られ，メタボリックシン ドロームにかかわる糖尿病の発症と深い関わりをもって いる。しかし脂肪酸が脂肪毒性を引き起こす機構は明ら かになっておらず，以下に述べるように小胞体ストレス 応答を介する経路と, それ以外の経路が存在すると考え られる。現在は小胞体ストレス応答を介する経路の解析 が盛んである。小胞体ストレス応答が脂肪毒性の指標と して簡便に測定できることから, いろいろな培養細胞系 と代表的な脂肪酸を用いて, 脂肪毒性発生の機構が研究
されている。

小胞体ストレス応答とは, 哺乳動物細胞における小胞 体でのタンパク質の折り畳み不全に対応する防御反応で ある。様々な原因により, 小胞体でのタンパク質の合成 反応は阻害される場合がある。小胞体ストレス応答を起 こす要因を小胞体ストレスと呼ぶ。たとえば還元的な環 境下では，タンパク質の SS 結合形成ができず，正しい 折り㽪みは阻害される。糖タンパク質の場合は小胞体内 での糖鎖付加と糖鎖修飾が阻害されると, やはり夕ンパ ク質の正しい折り畳みは阻害される。こうした小胞体ス トレスが小胞体内での折り畳まれていないタンパク質の 増加を引き起こす。これを小胞体膜上に存在するセン サータンパク質が感知し, 最終的に転写因子を介して, 複数の遺伝子の発現を変化させる。その結果, 全般的な タンパク質合成の抑制や小胞体シャペロン（タンパク質 の正しい折り畳みを制御する）タンパク質の誘導のよう な，小胞体の状態を正常化しょうとする反応が起きる。 これが小胞体ストレス応答, またはUnfolded Protein Response（UPR）である。Fig. 2 に小胞体ストレス応答 と，これにかかわる因子の全体像を示した ${ }^{8)}$ 。

小胞体ストレス応答は段階的に変化し, ストレスが軽 度であればタンパク質翻訳の抑制や, シャペロンタンパ ク質の誘導, 折り畳み異常タンパク質の分解により, 細 胞機能を維持しようとするが, ストレスが強い場合はア ポトーシスに至らしめ, 個体の保護を優先する。現在ま でに, 小胞体ストレス応答による細胞死は神経変性疾患 や, 癌, 糖尿病, 動脈硬化など多くの疾患に関与するこ 


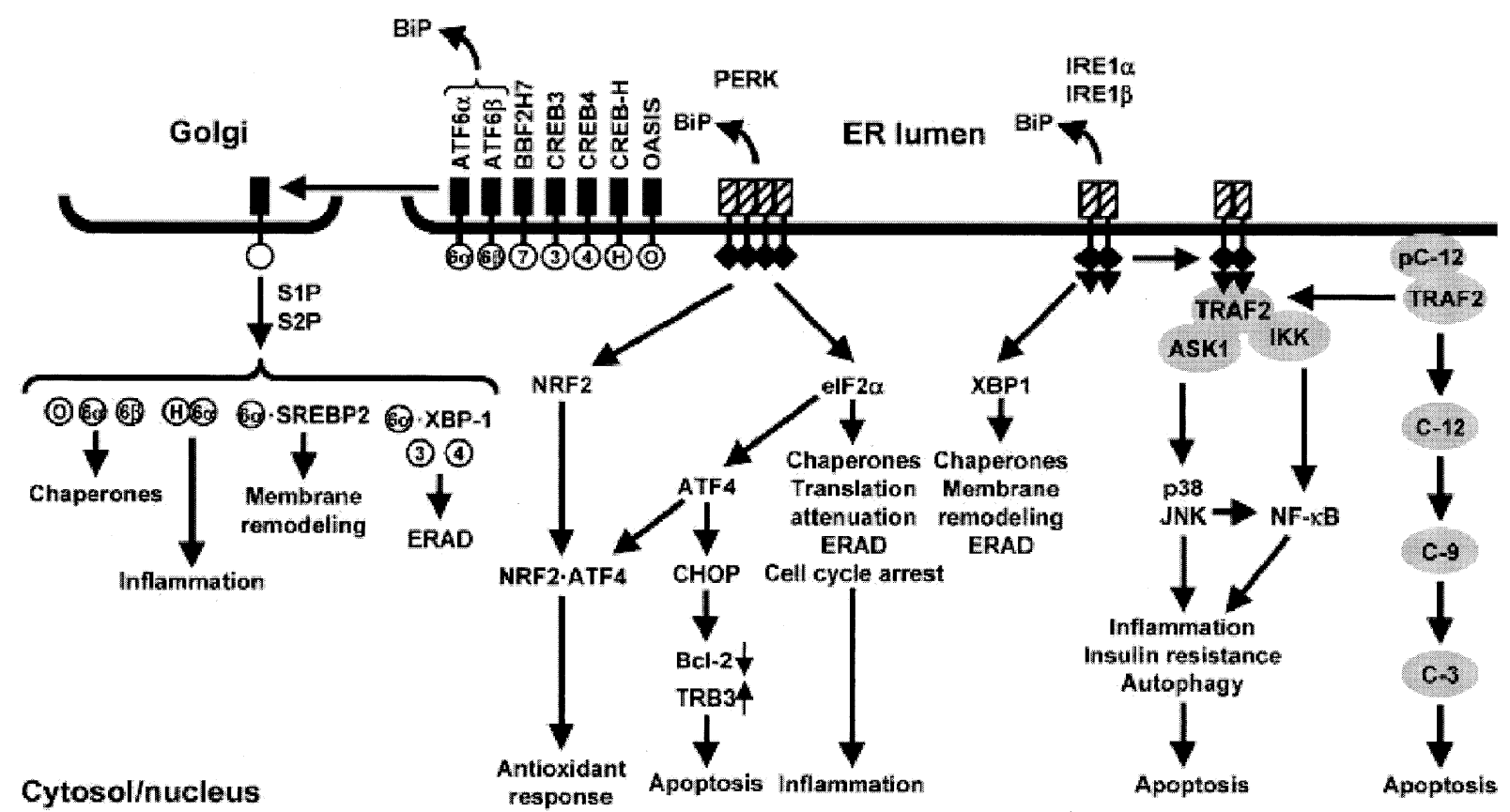

Fig. 2 小胞体ストレス応答とそれに関わる分子 ${ }^{8)}$

とが知られている。こうした研究が盛んなのは, 過剰な 遊離脂肪酸の細胞への流入が, 脂質合成の場である小胞 体膜の脂質組成の異常を引き起こし, 膜の流動性の変化 と機能の異常につながり, 小胞体ストレス応答を引き起 こすと考えられるからである。

\section{9 脂肪酸の種類と小胞体ストレス}

小胞体ストレス応答を指標にした脂肪酸による細胞毒 性の研究から, 脂肪酸の種類により引き起こされる脂肪 毒性の程度が異なること, また細胞の種類によっても大 きく異なることがわかってきた。Diakogiannaki らによ れば9)，ラット荤 $\beta$ 細胞由来の BRIN-BD 11 培養細胞を 用いた実験では， $0.025 \mathrm{mM}$ から $0.25 \mathrm{mM}$ のパルミチン 酸により, 小胞体ストレス応答がみられたが, $1 \mathrm{mM}$ の パルミトレイン酸では小胞体ストレス応答は観測されな かった。一方でパルミチン酸とパルミトレイン酸を混合 して添加すると, 小胞体ストレス応答は抑制されること が示された。また，チャイニーズハムスター卵母細胞由 来の $\mathrm{CHO}$ 細胞では，パルミチン酸添加では小胞体スト レス応答が生じるが，オレイン酸添加では生じないと報 告されている。最近 Kato らは7), マウスから得た膵島を パルミチン酸で処理すると, インスリン分泌能が障害さ れるが，エイコサペンタエン酸を加えるとインスリン分 泌機能が回復することを示した。このように，一般的に 飽和脂肪酸は不飽和脂肪酸よりも脂肪毒性が強いという こと, 不飽和脂肪酸は飽和脂肪酸の脂肪毒性を抑制する ということが報告されている ${ }^{10)}$ 。
一方，不飽和トランス脂肪酸であるエライジン酸は， 肝や上皮の培養細胞系をアポトーシスに導くことが報告 されている ${ }^{11)}$ 。共役リノール酸（trans-10, cis-12-linoleic acid）がマウス乳がん由来細胞において, 小胞体スト レス応答を引き起こすという報告もある。Wei らも共役 リノール酸が飽和脂肪酸により起きる小胞体ストレス応 答を増強することを報告した ${ }^{12)}$ 。これらの知見は, 脂肪 酸が小胞体ストレス応答を引き起こすか否かには, 脂肪 酸の不飽和度よりも分子の形が重要であり，膜の流動性 を下げる直鎖に近い脂肪酸は同じ影響を与えることを示 唆していそうだが，流動性の低下が脂肪毒性の主たる原 因であるとしても, より詳細な解析が必要である。なぜ ならば，これらの脂肪酸が膜脂質に取り达まれ，それ自 身が膜の流動性を下げる可能性のほかに，Wei らが報告 している共役リノール酸によるSCD 1 活性の低下の方が 主たる原因である可能性がある。過剩な飽和脂肪酸によ る小胞体ストレス応答の誘導に対する共役リノール酸の 増強効果や，低濃度の不飽和脂肪酸同時添加による抑制 効果は, 単純な飽和脂肪酸量の増加のみでは説明しにく い。共役リノール酸や同時添加の不飽和脂肪酸が, 脂肪 酸リモデリングや中性脂質の合成の活性あるいは発現量 に影響を与えている可能性がある。Spiegelman らのグ ループは, 食物由来の脂肪酸が, 脂肪酸合成系リモデリ ング系, リポタンパク質合成分泌などにかかわる酵素遺 伝子発現に対して, 転写因子 SREBP とコアクチベー ターPGC- $1 \beta$ を介して作用する，という実験結果を報告 している $(F i g .3)^{13)}$ 。培養細胞と遺伝子改変動物を用い 


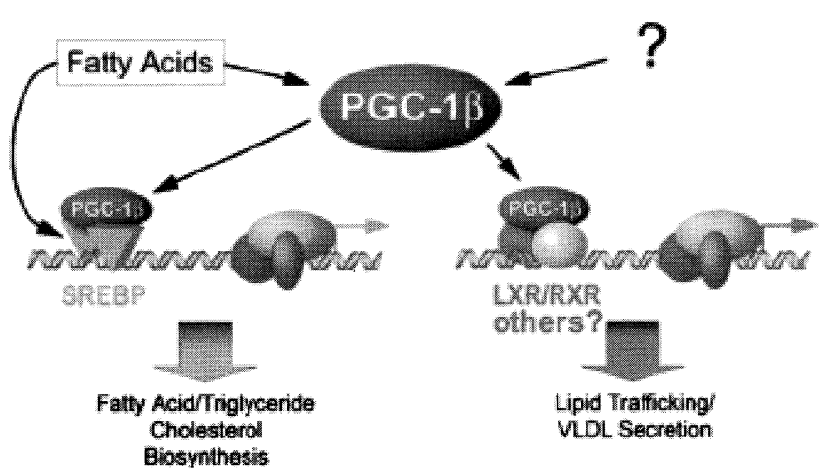

Fig. 3 食物由来飽和脂肪酸による転写因子 SREBP とコアク チベーター PGC-1 $\beta$ を介した転写調節 ${ }^{13)}$

たこの結果も, 食物由来の脂肪酸がそのまま膜脂質の組 成に影響するのではないことを示している。

\section{0 細胞の種類と脂肪酸による小胞体ストレス応答}

一方, 細胞の種類によって, 同じ脂肪酸でも小胞体ス トレス応答を指標にした脂肪毒性の程度が異なるという 結果も得られている。遊離脂肪酸の影響について盛んに 研究がなされている荤 $\beta$ 細胞では, 代表的な飽和脂肪酸 であるパルミチン酸の数百 $\mu \mathrm{M}$ の添加により, 顕著なア ポトーシスと小胞体ストレス応答を引き起こすことが知 られている。それに対して, 初代培養肝細胞は, 同様の パルミチン酸添加では, 細胞死や小胞体ストレス応答は 顕著ではない。また興味深いことに，ヒト胎児腎臓由来 の上皮系細胞である HEK 293 細胞では, 飽和脂肪酸の みならず不飽和脂肪酸であるリノール酸の添加でも小胞 体ストレス応答が起きることをわれわれは見出している (Ashibe ら未発表)。このように，脂肪毒性に対する細 胞の適応力は細胞の種類により大きく異なる。こうした 違いは, 体内では組織ごとに流入する脂肪酸の種類と量 が大きく異なることの反映である。脂肪酸の酸化能力と 脂肪酸リモデリングの必要性と能力が細胞ごとに異な る。そして, 脂肪酸を中性脂肪として脂肪滴に隔離する 能力の違いが脂肪毒性への耐性度の違いとなるものと考 えられる。

\section{1 脂肪滴形成と脂肪毒性}

ほとんどの細胞は, 余㮃の脂肪酸を中性脂肪に変換 し，脂肪滴に蓄えることができる。脂肪滴の中心はトリ アシルグリセリド，コレステロールエステルといった中 性脂質で，周りを両親媒性のリン脂質が取り囲み，そこ に脂質の輸送や代謝, リモデリングにかかわる酵素タン パク質が付着している。こうした共通構造のほかに, 細 胞によって異なる付着タンパク存在し, これが細胞ごと に異なる脂肪滴の生理的役割を支えている ${ }^{14)}$ 。脂肪細胞
での脂肪滴形成は，体内の中長期的なエネルギー貯蔵機 構の主体である。一方, 肝臓には食物由来の種類の雑多 な脂肪酸を含む脂質の一時的な大量流入に対して, 迅速 な脂肪滴形成能力が必須であり，脂肪酸をリモデリング 後血中にリポタンパク質として分泌し，他の組織の負荷 とならない組成の脂肪酸を分配する役目がある。このよ うに肝臓と末梢とでは接する脂肪酸の種類と量に大きな 違いがあるため，いろいろな培養細胞を用いた実験結果 の解釈には注意が必要である。

Borradaile らは，CHO 細胞を $500 \mu \mathrm{M}$ のパルミチン酸 で処理すると, 小胞体画分に存在するトリアシルグリセ リド中の飽和脂肪酸の比率が約 3 倍に増加し, フォス ファチジルコリン中の飽和脂肪酸の比率が約 1.5 倍に増 加することを示した ${ }^{15)}$ 。この結果は, チャイニーズハム スターの卵巣から樹立された繊維芽細胞株でも，過剰な パルミチン酸に対処するために, 脂肪滴形成を始めるこ と, 対処しきれない分がリン脂質に取り达まれ小胞体膜 の流動性を下げている可能性を示している。脂肪滴形成 は良いとして，過剩の飽和脂肪酸が膜脂質に取り込まれ ることを直接示す彼らの結果は，はたして生体内の答 を反映しているのか疑問が残る。CHO 細胞に培地成分 として連続的に添加された高濃度飽和脂肪酸の影響を, 生体内での飽和脂肪酸の脂肪毒性と同じとすることには 疑問が残る。

\section{2 脂肪毒性と脂質過酸化}

脂肪毒性は小胞体ストレスの観点からの研究が始まる 以前より脂質過酸化から論じられてきた。リノール酸, アラキドン酸のような多価不飽和脂肪酸（PUFAs）は 活性酸素種（ROS）により，非酵素的で複雑な反応を介 し, 脂質過酸化反応を起こし, 多種類の中間体を生じた 後，より低分子な化合物に分解される。PUFAs の脂質 過酸化により，まず，ヒドロペルオキシドなどが生じ， 最終的にへキサナールやアクロレインなどの飽和または 不飽和アルデヒド，グリオキサール，メチルグリオキ サール, マロンジアルデヒドなどのジカルボニル, そし て 4-ヒドロキシ-2-ノネナール (4-HNE)，4-ヒドロキ シ-2-ヘキサナール (4-HHE) のアルデヒドが生じる ${ }^{16)}$ 。 これらのアルデヒドは細胞のミトコンドリアの機能を障 害し，また，アポトーシスを引き起こすことが知られて いる。これらのアルデヒドは組織中のタンパク質と結合 して, 付加体として高度脂質過酸化終末産物 (Advanced Lipid Peroxidation End Products; ALE) を 形成する。タンパク質が ALE となることにより，タン パク質の機能は障害され，細胞障害へとつながると考え られている ${ }^{17)}$ 。ALEに変化したタンパク質はプロテア 
ソームによる分解に抵抗性があるため, 細胞内に凝集体 を形成することもある。

アテローム性動脈硬化症の病巣部位のプラークにおけ る 4-HNE 付加体, マロンジアルデヒド付加体の存在は 本疾患の分子的指標とされている。アルツハイマー型認 知症, パーキンソン病などの神経変性疾患の病巣部で 4-HNE 付加体の存在が確認されている。しかしながら, 培養細胞を用い, リノール酸を比較的高濃度で添加して も, 数日程度の処理では, 細胞に細胞死などの顕著な影 響は観察されない。この結果の違いは脂質過酸化による 脂肪毒性と小胞体ストレス応答を介した脂肪毒性とで は，その時間的スケールや脂肪毒性が生じる条件が，か なり異なることを示している。

Fig. 4 は，パルミチン酸の脂肪毒性を説明したもので はあるが，脂肪毒性における小胞体ストレス応答と ROSの関与, そしてそれらに対して防御的に働く脂肪 滴形成をひとまとめにしたモデル図である ${ }^{15)}$ 。各ステッ プは, 個々の実験で得られた結果に基づいてはいるもの の, 生体内のひとつの細胞の中で起こることが示されて いるわけではなく, 各ステップの詳細な機構解明はこれ からである。

\section{3 その他のアプローチ}

脂肪毒性発生メカニズム解明のために，小胞体ストレ ス応答やALEの形成に焦点を絞らずに, 異なる脂肪酸 負荷に応答する遺伝子を網羅的に解析する, というアプ ローチもみられる。Lockridge らは，ラット初代心筋細 胞に飽和あるいは不飽和脂肪酸の負荷をかけ，応答する 遺伝子を時間経過を追って調べた。その結果, 飽和脂肪 酸と不飽和脂肪酸では, 同じ遺伝子でも発現誘導の持続 性に差があること, 異なる脂肪滴付着夕ンパク質を誘導 することを見出した。心筋細胞では飽和脂肪酸のみが, 他組織では主要な脂肪滴夕ンパク質であるADRP (adipocyte differentiation-related protein) の発現を誘

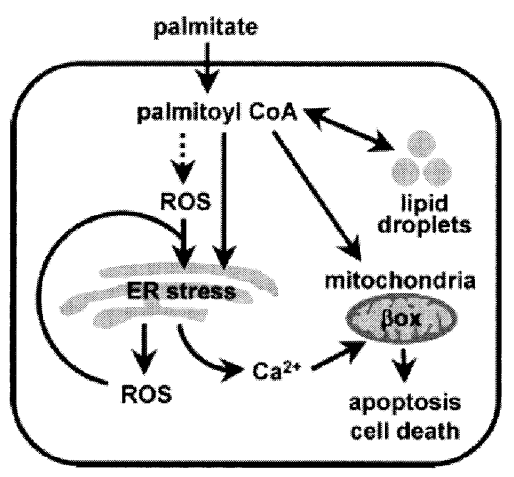

Fig. 4 パルミチン酸による脂肪毒性発生機構と脂肪滴形成 による防御を示すモデル図 ${ }^{15)}$
導することに注目し，乳腺上皮細胞ではADRPで覆わ れた脂肪滴がキサンチンオキシダーゼを特異的に活性化 するという知見を参考にして, 飽和脂肪酸が ADRP の 多い脂肪滴を形成し，キサンチンオキシダーゼが活性化 し ROS が生じ，細胞死に至るという，新たな仮説を提 出した。これを検証する生化学的データが待たれるが, 飽和脂肪酸と不飽和脂肪酸とでは, 遺伝子誘導の時間経 過に差があるという知見と, 誘導形成される脂肪滴に質 的な差がある可能性の指摘は興味深い。

\section{4 脂肪毒性研究の問題点}

脂肪毒性は細胞の生存・機能に対して負に働くもので ある。非生理的条件下での脂質による毒性では，細胞に いくらダメージが観察されても，たとえその機構が解明 されたとしても, 何の生物学的意味もない。とくに培養 細胞を用いて行う実験では，その点に十分留意する必要 があるし, 結果の解釈も慎重でなければならない。現在 までの研究報告には, 実験に用いている細胞がどの組織 に由来し，その組織は体全体の脂質代謝においてどのよ うな役割を担っているか，といった点を考慮に入れてい ないものが散見される。培養細胞による比較的短期的な 実験で観察することが可能であるため, 最近は脂肪毒性 の指標として小胞体ストレス応答がとり上げられること が多い。しかし, 脂肪毒性と小胞体ストレス応答は同一 ではない。実際の生体内での脂肪毒性において，小胞体 ストレス応答がどれだけ重要であるか, 慎重に検討する 必要がある。飽和脂肪酸 $\rightarrow$ 膜の流動性減少 $\rightarrow$ 小胞体ス卜 レス応答 $\rightarrow$ 脂肪毒性という図式は単純明快だが，脂肪酸 による脂肪毒性発生の機構は決して明らかになったわけ ではない。動物の食物由来の脂質変動に対する適応能力 は高い。われわれは, 肝臓での脂質代謝の重要な調節因 子である PPAR $\alpha$ のノックウトマウスと野生マウスの 脂質プロファイルを比較して，一過的な脂肪負荷時には 脂質プロファイルに大きな差がみられるが, 通常食によ る長期飼育では，まったく差がないことを観察してい る。動物は重要な転写因子を欠いても, 多重な代謝リモ デリング系によって脂質恒常性を維持できる高い適応性 をもっていると思われる。PPAR $\alpha$ の役割を, 肝蔵にお ける脂肪酸異化代謝の充進と脂質恒常性の維持が中心と する従来の考えに対して，われわれは，食物摂取による 急激な脂質の質と量の変動に対する短期応答システムの 調節を主要なものとする, と想像している。短期応答で 見られる急激な変化は, 必ずしもシステムの破たんの始 まりや結果ではない。脂肪毒性のマーカーとして採用さ れている ER ストレス応答も, 防御システムが稼働して いることを示しているのであって, 細胞が脂肪毒性を処 
理できなくなったことを意味しない。脂肪毒性を疾病と の関わりで考える場合でも, 飽和脂肪酸や不飽和脂肪酸 の短期的な影響を短絡的に解釈することは避けなければ ならない。最終的なシステムの破たん, 疾病の発症に直 接かかわるか否かを, 長期的な視点からの解析する必要 があろう。

\section{文 献}

1) P.A. Watkins, D. Maiguel, Z. Jia \& J. Pevsner, J. Lipid Res., 48, 2736-50 (2007).

2) A. Jakobsson, R. Westerberg \& A. Jacobsson, Prog. Lipid Res., 45, 237-49 (2006).

3) K. Hashimoto, A.C. Yoshizawa, S. Okuda et al., J. Lipid Res., 49, 183-191 (2008).

4) H. Sampath, M. Miyazaki, A. Dobrzyn \& J.M. Ntambi, J. Biol. Chem., 282, 2483-93, (2006).

5) T. Matsuzaka, H. Shimano, N. Yahagi, T. Kato et al., Nat. Med, 13, 1193-202 (2007).

6) D.B. Jump, D. Botolin, Y. wang et al., J. Nutr, 135, 2503-6 (2005)
7) T. Kato, H. Shimano, T. Yamamoto, M. Ishikawa et al., Diabetes (2008). (in press)

8) M. Schroder, Cell Mol. Life Sci., 65, 862-94(2008).

9) E. Diakogiannaki, H.J. Welters \& N.G. Morgan, J. Endocrinol., 197, 553-63 (2008).

10) U. Riserus, Curr. Opin. Clin. Nutr. Metab. Care, 11, 100-5 (2008).

11) D. Zapolska-Downar, A. Kosmider \& M. Naruszewicz, J. Physiol. Pharmacol., 56, 611-25 (2005).

12) Y. Wei, D. Wang \& M.J. Pagliassotti, Mol. Cell. Biochem., 303, 105-13 (2007).

13) J. Lin, R. Young, P.T. Tarr, P.H. Wu et al., Cell, 120, 261-73 (2005).

14) S. Martin \& R.G. Parton, Nat. Rev. Mol. Cell Biol., 7, 373-8 (2006).

15) N.M. Borradaile, X. Han, J.D. Harp et al., J. Lipid Res., 47, 2726-37 (2006).

16) C. Schneider, N.A. Porter \& A.R. Brash, J. Biol. Chem., 283, 15539-43 (2008).

17) A. Negre-Salvayre, C. Coatrieux, C. Ingueneau \& R. Salvayre, Br. J. Pharmacol., 153, 6-20 (2008). 